\title{
Antihyperglycemic and Antihyperlipidemic of Karala (Momordica charantia) Fruits in Streptozotocin Induced Diabetic Rats
}

\author{
M. A. Hossain, M. Mostofa, D. Debnath, A. K. M. R. Alam, Z. Yasmin and N. F. Moitry
}

Department of Pharmacology, Bangladesh Agricultural University, Mymensingh

\begin{abstract}
To investigate the antihyperglycemic and antihyperlipidemic effect of Momordica charantia (Karala), the aqueous extract of the Karala fruit was tested on streptozotocin (STZ)-induced diabetic rats. Thirty six albino rats were used in the experiment, 30 diabetic and the remaining six as negative control $\left(\mathrm{T}_{1}\right)$. Diabetes was induced by administering (injecting) STZ at dose of $55 \mathrm{mg} / \mathrm{kg}$ body weight. Thirty diabetic animals were randomly divided into five groups such as diabetic control group (T2) without any application of treatment, and groups $\mathrm{T}_{3}, \mathrm{~T}_{4}, \mathrm{~T}_{5}$ and $\mathrm{T}_{6}$ were treated with aqueous extract of Karala fruits daily at the doses of 250 , 500 and $750 \mathrm{mg} / \mathrm{kg}$ and glibenclamide (at a dose of $5 \mathrm{mg} / \mathrm{kg}$ body weight) respectively. The body weight was taken and blood samples were collected from individual animal to determine glucose levels at 15 day interval up to 90 days. In addition, Asparate Transaminenase(AST), Alanine Transaminenase(ALT), Alkaline Phosphatase(ALP), Total cholesterol (TCh) and Triglyceride (TGA) were determined at day 15 and at the end of the experiment. All three doses of Karala extracts reduced diabetic induced blood sugar and the reduction is comparable with standard glibenclamide (GLM) dose particularly with higher doses Karala extracts (500 and 750mg). Karala also prevented body weight loss due to induced diabetes as did by GLM treatment.. The treatment also resulted in a significant reduction of Asparate Transaminenase(AST), Alanine Transaminenase(ALT), Alkaline Phosphatase(ALP), Total cholesterol (TCh) and Triglyceride (TGA) activities of treated rats when compared to the STZ induced diabetic rats. Higher doses of Karala $(500$ and $750 \mathrm{mg} / \mathrm{kg}$ ) are as effective as standard GLM dose on measured variables. This study demonstrated that Karala has hyperglycemia and antihyperlipidemic effect against STZ induced diabetic rats. These findings open the possibility of using Karala extract to treat diabetic animal and human patients although further research is warranted.
\end{abstract}

Key words: Antihyperglycemic, Antihyperlipidemic, Diabetes, Momordica Charantia, Streptozotocin

\section{Introduction}

Diabetes mellitus is a complex disorder that characterized by hyperglycemia resulting from malfunction in insulin secretion and/or insulin action both causing by impaired metabolism of glucose, lipids and protein (Scheen, 1997). The chronic hyperglycemia of diabetes is associated with long term damage, dysfunction and failure of various organs such as kidney and eyes (Lyra et al., 2006). In diabetic rats, the utilization of impaired carbohydrate leads to accelerate lipolysis, resulted in hyperlipidemia (Morel, D.W. and G.M. Chisolm, 1989 and Granner, D.K., 1996) and other complications related to lipid metabolism. Diabetes also increase the risk of heart and blood vessel diseases and increase GOT, GPT, total cholesterol (TC) and triglyceride (TG) in the blood at various levels (King et al. 1998).

Despite the presence of known antidiabetic medicine in the pharmaceutical market, diabetes and the related complications continued to be a major medical problem. Recently, some medicinal plants have been reported to be useful in diabetes worldwide and have been used empirically as antidiabetic and antihyperlipidemic remedies (Mitra et al, 1996; Shukla et al., 2000; Bhattaram et al., 2002; Huang et al., 2005;). Antihyperglycemic effects of these plants are attributed to their ability to restore the function of pancreatic tissues by causing an increase in insulin output or inhibit the intestinal absorption of glucose or by facilitating of metabolites in insulin dependent processes. More than 400 plant species having hypoglycemic activity have been available in literature (Oliver-Bever, 1986; and Rai,1995). However, searching for new antidiabetic drugs from natural plants is still attractive because they contain substances which take alternative and safe effect on diabetes mellitus. Most of plants contain glycosides, alkaloids, terpenoids, flavonoids, cartenoids, etc., that are frequently implicated as having antidiabetic effect (Loew, D. and M. Kaszkin, 2002).

M. charantia $(M C) \mathrm{LINN}$, commonly referred to as bitter melon, bitter gourd, balsam pear, or karala, belongs to the Cucurbitaceous family. It a climbing plant, cultivted throughout Southern Asia. Its fruits are very cheap and available throughout the year. Immature fruits are used to prepare different dishes for human consumption. There are two varieties of this fruits based on size and shape. The large variety is long, oblong and pale green in color. The other one is small, little oval and dark green in color. Both the varieties are bitter in taste. The pulp is blood red or scarlet after dehiscence. The seeds are dappled, flat, thick notched margin, red aril in morphology and it is white color in raw fruits and become red when they 
are ripe. The entire plant has been reported to contain a trace amount of alkaloids, glycosides, saponins and orthophthalic acid, Charantin, an insulin-like peptide has been reported in this plant (Chevallier, 1996). Different parts of these plants have been used in medicine for a number of ailments besides diabetes.(Ganguly and Das, 2000; Jayasooriya et al., 2000).

Hence, in the present study the aqueous extracts of $M$. charantia friuts, were evaluated for the potential antidiabetic and antihyperlipidemic effect on streptozotocin -induced diabetic rats and compared with the effect with glibenclamide, a standard antidiabetic medicine. The effect of the plant extract $M$. charantia on blood glucose, body weight (BW), GOT, GPT, total cholesterol (TC) and triglyceride (TG) in the blood were determined.

\section{Materials and Methods}

Streptozotocin was obtained from Sigma Chemical Co., St Louis, U.S.A and tablets dibenol ${ }^{\circledR}$ from Square Pharmaceuticals, Bangladesh, and each dibenol ${ }^{\circledR}$ tablet contains 5mg glibenclamide. Fresh unripe fruits of $M$. charantia (Karala) were procured from the Kamal Ranjit market, BAU campus, Mymensingh.Karala fruits were carefully and thoroughly washed in tap water. The fruits were sliced into two halves and the seeds were removed manually, then the fleshy parts were cut into small pieces. Then one $\mathrm{kg}$ seedless flesh was put in to an electric juicer and make juice now it filtered through a piece of clean silk cloth.

Thirty six apparently healthy mixed albino rats, Long Evens strain (Ratus norvegicus) weighting between $150-200 \mathrm{gm}$ used in this experiment All the rats were kept in an animal housed in grilled cages at room temperature $21-23^{\circ \mathrm{C}}$, humidity $45-50 \%$ and maintained under a constant twelve hours light and dark cycle. Animal feed, used in this experiment was procured from the International Center for Diarrheal Disease Research, Bangladesh (ICDDRB), Mohakhali, Dhaka. Prior to the commencement of the experiment, all the rats were acclimatized to the new environment for a period of 15 days. After overnight fasting, fresh solution of Streptozotocin was injected to experimental animals single intraperitoneally at the dose of $55 \mathrm{mgkg}^{-1}$ body weight in a volume of $1 \mathrm{ml} / \mathrm{kg}$ body weight (Chattopadhyay et al., 1997). The control rats were injected the same amount of $0.1 \mathrm{M}$ sodium citrate buffer. The animals were allowed to drink $5 \%$ glucose solution overnight to reduce the drug-induced hypoglycemic mortality. After a week of streptozotocin administration, fasting blood glucose levels were determined by accu-check (strip method). The rats showing glycosuria and hyperglycemia (blood glucose range of above 250 $\mathrm{mg} / \mathrm{dl}$ ) were considered as diabetic rats and used for the further experiments. The change in the body weight was observed throughout the treatment period in the experimental animals.

\section{Experimental design}

In the experiment, a total of 36 rats (30 diabetic surviving rats, 6 normal rats) were used. The rats were divided into six groups of six rats each after the induction of Streptozotocin diabetes. Group $\mathrm{T}_{1}$ : normal rats. Group $\mathrm{T}_{2}$ : diabetic control rats. Group $\mathrm{T}_{3}$ :diabetic rats given extract of $M$. charantia fruits @ $250 \mathrm{mg} / \mathrm{kg}$ bd wt., Group $\mathrm{T}_{4}$ : diabetic rats given extract of $M$. charantia fruits @ 500mg/kg bd wt., Group $\mathrm{T}_{5}$ : diabetic rats given extract of $M$. charantia fruits @ 750mg/kg bd wt., Group $\mathrm{T}_{6}$ : diabetic rats given dibenol ${ }^{\circ}$ (glibenclamide) @ $5 \mathrm{mg} / \mathrm{kg}$ bd wt.

\section{Administration extracts and drug}

Group $\mathrm{T}_{3}, \mathrm{~T}_{4}$ and $\mathrm{T}_{5}$ diabetic rats were treated aqueous extract of $M$. charantia (Karala) fruits at the doses of 250,500 and $750 \mathrm{mg} / \mathrm{kg}$ body weight respectively. Group $\mathrm{T}_{6}$ diabetic rats were treated with aqueous solution of dibenol ${ }^{\circledR}$ (glibenclamide) $@ 5 \mathrm{mg} / \mathrm{kg}$ body weight. All the doses were started orally administrated by an intragastric tube to the rats except the normal and diabetic control up to day 90 . No detectable irritation or restlessness was observed after each drug administration.

\section{Collection of blood for biochemical assays}

For determination of biochemical parameter fasting blood samples were collected from the tail tip of each rat and blood was collected in the sterile glass test tubes. The blood containing tubes were placed in a slanting position at room temperature for 4 hours. The tubes were then incubated overnight in the refrigerator $\left(4^{\circ \mathrm{C}}\right)$. The serum samples were separated and centrifuged to get rid of unwanted blood cells. Serum samples were stored at $-20^{\circ} \mathrm{C}$ until further analysis. The method used for biochemical assays are tabulated in Table 1. 
Table 1. Assay methods used for various biochemical analyses

\begin{tabular}{|l|l|}
\hline \multicolumn{1}{|c|}{ Parameter Method } & \\
\hline blood glucose & by accu-check advantage blood glucose system (strip method) \\
\hline serum aspartate aminotransferase (AST, EC 2.6.1.1) & Deneke et al., 1985 \\
\hline serum alanine aminotrasferase (ALT EC 2.6.1.2) & Deneke et al., 1985 \\
\hline serum alkaline phosphatase (ALP, 3.1.3.1) & (Deutsche Gesellschaft fur Klinische Chemie, 1972). \\
\hline Serum total cholesterol & (Trinder, 1969). \\
\hline Serum Triglyceride & (Tietz, 1990). \\
\hline Serum urea & (Fawcetl. and Soctt. 1960). \\
\hline Serum creatinine & (Tietz, 1987) using (Jaffe's 1886) \\
\hline Serum uric acid & (Barham. and Trinder. 1972). \\
\hline
\end{tabular}

\section{Results}

\section{Statistical analysis}

All recorded and calculated data were subjected to analysis of variance (ANOVA) in a completely randomize design (CRD) using MSTAT computer package (Freed, 1992). Multiple Range Test was performed to compare mean differences among treatments (Duncan, 1955). The effect of dose was evaluated using linear regression analysis.

\section{Body weight}

The BW of diabetic rats (Group $\mathrm{T}_{2}$ ) was significantly lower than negative control rats (Group $\mathrm{T}_{1}$ ), in fact, there was no increase in BW with age of rats in the diabetic rats. The BW of treated groups (Groups $\mathrm{T}_{3}$, $\mathrm{T}_{4}, \mathrm{~T}_{5}$, and $\mathrm{T}_{6}$ ) was higher than untreated diabetic group $\left(\mathrm{T}_{2}\right)$ all along. The BW of treated groups $\mathrm{T}_{4}, \mathrm{~T}_{5}$, and $\mathrm{T}_{6}$ is comparable to negative control group throughout the life of the experiment

(Table 2).

Table 2. Effects of aqueous extract of M. charantia fruits and Glibenclamide on body weight (g) in STZ treated diabetic rats

\begin{tabular}{|c|c|c|c|c|c|c|}
\hline \multirow[t]{3}{*}{ Group } & Pre treatment & \multicolumn{5}{|c|}{ Post- treatment } \\
\hline & day 0 & day 15 & day 30 & day 45 & day 60 & day 90 \\
\hline & mean \pm SD & mean \pm SD & mean \pm SD & mean \pm SD & mean \pm SD & mean \pm SD \\
\hline $\begin{array}{c}\mathrm{T}_{1} \\
\text { (Normal } \\
\text { Control) }\end{array}$ & $170.32 \pm 15.53$ & $182.63 \pm 14.03 \mathrm{abc}$ & $192.08 \pm 10.95 \mathrm{a}$ & $201.18 \pm 11.30 \mathrm{a}$ & $210.93 \pm 13.86 \mathrm{a}$ & $234.79 \pm 11.37 \mathrm{a}$ \\
\hline $\begin{array}{c}\mathrm{T}_{2} \\
\text { (diabetic } \\
\text { Control) }\end{array}$ & $167.33 \pm 12.10$ & $\begin{array}{c}157.23 \pm 13.05 \mathrm{~d} \\
(-13.91 \%)\end{array}$ & $\begin{array}{c}153.12 \pm 13.12 \mathrm{c} \\
(-20.28 \%)\end{array}$ & $\begin{array}{c}151.73 \pm 13.25 \mathrm{e} \\
(-24.58 \%)\end{array}$ & $\begin{array}{c}149.97 \pm 13.32 \mathrm{c} \\
(-28.90 \%)\end{array}$ & $\begin{array}{c}149.50 \pm 13.00 f \\
(-36.33 \%)\end{array}$ \\
\hline $\begin{array}{c}\mathrm{T}_{3} \\
\text { (Diabetic } \\
\text { +MCFEt- } \\
\text { 250mg) }\end{array}$ & $164.27 \pm 12.69$ & $\begin{array}{c}164.90 \pm 12.31 \mathrm{~cd} \\
\quad(+4.88 \%)\end{array}$ & $\begin{array}{c}167.92 \pm 12.99 b c \\
(+9.67 \%)\end{array}$ & $\begin{array}{c}175.07 \pm 12.93 \mathrm{~d} \\
(+15.38 \%)\end{array}$ & $\begin{array}{c}185.92 \pm 13.09 \mathrm{ab} \\
(+23.97 \%)\end{array}$ & $\begin{array}{c}188.82 \pm 23.19 \mathrm{e} \\
(+26.30 \%)\end{array}$ \\
\hline $\begin{array}{c}\mathrm{T}_{4} \\
\text { (Diabetic } \\
+ \text { MCFEt- } \\
500 \mathrm{mg} \text { ) }\end{array}$ & $172.87 \pm 13.57$ & $\begin{array}{c}175.75 \pm 12.97 \mathrm{a}-\mathrm{d} \\
\quad(+11.78 \%)\end{array}$ & $\begin{array}{c}183.47 \pm 12.78 \mathrm{ab} \\
(+19.82 \%)\end{array}$ & $\begin{array}{c}193.52 \pm 12.77 \mathrm{a}-\mathrm{d} \\
\quad(+27.54 \%)\end{array}$ & $\begin{array}{c}199.07 \pm 12.44 \mathrm{a} \\
(+32.74 \%)\end{array}$ & $\begin{array}{c}207.65 \pm 12.34 b- \\
\mathrm{e} \\
(+38.90 \%)\end{array}$ \\
\hline $\begin{array}{c}\mathrm{T}_{5} \\
\text { (Diabetic } \\
\text { +MCFEt- } \\
750 \mathrm{mg} \text { ) }\end{array}$ & $169.70 \pm 11.80$ & $\begin{array}{c}175.67 \pm 11.47 \mathrm{a}-\mathrm{d} \\
(+11.73 \%)\end{array}$ & $\begin{array}{c}185.00 \pm 10.83 \mathrm{ab} \\
(+20.82 \%)\end{array}$ & $\begin{array}{c}195.57 \pm 9.77 \mathrm{abc} \\
(+28.89 \%)\end{array}$ & $\begin{array}{c}204.75 \pm 8.94 a \\
(+36.53 \%)\end{array}$ & $\begin{array}{c}214.38 \pm 8.60 b c \\
\quad(+43.40 \%)\end{array}$ \\
\hline $\begin{array}{c}\mathrm{T}_{6} \\
\text { Diabetic }+ \\
\text { Glibenclimide- } \\
5 \mathrm{mg}\end{array}$ & $170.07 \pm 17.39$ & $\begin{array}{c}174.03 \pm 16.96 \mathrm{a}-\mathrm{d} \\
(+10.68 \%)\end{array}$ & $\begin{array}{c}183.27 \pm 16.75 \mathrm{ab} \\
\quad(+19.69 \%)\end{array}$ & $\begin{array}{c}199.63 \pm 15.21 \mathrm{ab} \\
(+31.57 \%)\end{array}$ & $\begin{array}{c}209.89 \pm 15.08 \mathrm{a} \\
(+39.95 \%)\end{array}$ & $\begin{array}{c}221.57 \pm 14.99 \mathrm{ab} \\
(+48.21 \%)\end{array}$ \\
\hline $\begin{array}{c}\text { Level of } \\
\text { significance }\end{array}$ & NS & $* *$ & $* *$ & $* *$ & $* *$ & $* *$ \\
\hline
\end{tabular}

NS=Not significant, ${ }^{*} *=\mathrm{P}<0.01$, values in each column bearing dissimilar letter(s) differed significantly, \% change in diabetic control was calculated against normal control and rests were computed against diabetic control group. 


\section{Blood glucose levels}

The fasting blood glucose (FBG) level negative control group $\left(\mathrm{T}_{1}\right)$ was the lowest in all measurement days, whereas untreated diabetic group $\left(\mathrm{T}_{2}\right)$ had the highest FBG and remained the highest throughout the experiment (Table 3). The treated diabetic group had intermediate levels of FBG throughout the experiment. The higher doses of Karala extract produced similar results, which are comparable with glibenclamide treatment. $M$. charantia

Table 3. Effects of aqueous extract of $M$. charantia fruits and Glibenclamide on blood glucose ( $\mathrm{m} \mathrm{mol/L}$ ) level in STZ treated diabetic rats

\begin{tabular}{|c|c|c|c|c|c|c|c|}
\hline \multirow[t]{3}{*}{ Group } & Pre treatment & \multicolumn{6}{|c|}{ Post- treatment } \\
\hline & day 0 & day 15 & day 30 & day 45 & day 60 & day 75 & day 90 \\
\hline & mean \pm SD & mean \pm SD & mean \pm SD & mean \pm SD & mean \pm SD & mean \pm SD & mean \pm SD \\
\hline $\begin{array}{l}\mathrm{T}_{1} \\
\text { (Norma } \\
\text { 1Control) }\end{array}$ & $4.53 \pm 0.08$ & $4.58 \pm 0.08 \mathrm{c}$ & $4.60 \pm 0.14 \mathrm{~d}$ & $4.62 \pm 0.17 \mathrm{~g}$ & $4.63 \pm 0.22 \mathrm{k}$ & $4.65 \pm 0.12 \mathrm{i}$ & $4.73 \pm 0.25 \mathrm{i}$ \\
\hline $\begin{array}{c}\mathrm{T}_{2} \\
\text { (diabetic } \\
\text { Control) }\end{array}$ & $14.08 \pm 0.23$ & $\begin{array}{l}15.42 \pm 0.42 \mathrm{a} \\
(+236.68 \%)\end{array}$ & $\begin{array}{l}16.73 \pm 0.33 a \\
(+263.70 \%)\end{array}$ & $\begin{array}{l}17.42 \pm 0.42 \mathrm{a} \\
(+277.06 \%)\end{array}$ & $\begin{array}{l}18.22 \pm 0.39 a \\
(+293.52 \%)\end{array}$ & $\begin{array}{l}18.82 \pm 0.24 a \\
(+304.73 \%)\end{array}$ & $\begin{array}{l}20.05 \pm 0.56 a \\
(+323.89 \%)\end{array}$ \\
\hline $\begin{array}{c}\mathrm{T}_{3} \\
\text { (Diabetic } \\
+ \text { MCFEt- } \\
250 \mathrm{mg} \text { ) }\end{array}$ & $14.63 \pm 0.37$ & $\begin{array}{c}14.05 \pm 0.42 \mathrm{~b} \\
(-8.88 \%)\end{array}$ & $\begin{array}{c}13.23 \pm 0.38 c \\
(-20.92 \%)\end{array}$ & $\begin{array}{c}13.00 \pm 0.38 b-f \\
(-25.37 \%)\end{array}$ & $\begin{array}{c}12.53 \pm 0.29 \mathrm{c}-\mathrm{f} \\
(-31.22 \%)\end{array}$ & $\begin{array}{c}12.00 \pm 0.21 \mathrm{~cd} \\
(-36.23 \%)\end{array}$ & $\begin{array}{c}11.70 \pm 0.32 \mathrm{~cd} \\
(-41.65 \%)\end{array}$ \\
\hline $\begin{array}{c}\mathrm{T}_{4} \\
\text { (Diabetic } \\
+ \text { MCFEt- } \\
500 \mathrm{mg} \text { ) }\end{array}$ & $15.15 \pm 0.33$ & $\begin{array}{c}14.05 \pm 0.14 \mathrm{~b} \\
(-8.88 \%)\end{array}$ & $\begin{array}{c}13.15 \pm 0.14 \mathrm{c} \\
(-21.40 \%)\end{array}$ & $\begin{array}{c}12.13 \pm 0.20 \mathrm{f} \\
(-30.37 \%)\end{array}$ & $\begin{array}{c}11.88 \pm 0.13 \mathrm{fg} \\
\mathrm{h} \\
(-34.80 \%)\end{array}$ & $\begin{array}{c}11.00 \pm 0.23 \text { ef } \\
(-41.55 \%)\end{array}$ & $\begin{array}{c}10.15 \pm 0.16 \mathrm{f} \\
(-49.38 \%)\end{array}$ \\
\hline $\begin{array}{c}\mathrm{T}_{5} \\
\text { (Diabetic } \\
+ \text { MCFEt- } \\
750 \mathrm{mg} \text { ) }\end{array}$ & $15.50 \pm 0.62$ & $\begin{array}{c}14.17 \pm 0.82 \mathrm{~b} \\
(-8.10 \%)\end{array}$ & $\begin{array}{c}13.57 \pm 0.83 b c \\
(-18.89 \%)\end{array}$ & $\begin{array}{c}12.28 \pm 0.79 \mathrm{ef} \\
(-29.51 \%)\end{array}$ & $\begin{array}{c}10.47 \pm 0.75 \mathrm{j} \\
(-42.54 \%)\end{array}$ & $\begin{array}{c}9.33 \pm 0.83 \mathrm{~g} \\
(-50.43 \%)\end{array}$ & $\begin{array}{c}8.58 \pm 0.40 \mathrm{~g} \\
(-57.21 \%)\end{array}$ \\
\hline $\begin{array}{c}\mathrm{T}_{6} \\
\text { Diabetic }+ \\
\text { Glibenclimide- } \\
5 \mathrm{mg}\end{array}$ & $15.47 \pm 0.65$ & $\begin{array}{c}14.12 \pm 0.61 \mathrm{~b} \\
(-8.43 \%)\end{array}$ & $\begin{array}{c}13.60 \pm 0.61 b c \\
(-18.71 \%)\end{array}$ & $\begin{array}{c}12.52 \pm 0.63 \mathrm{de} \\
\mathrm{f} \\
(-28.13 \%)\end{array}$ & $\begin{array}{c}10.68 \pm 0.60 \mathrm{ij} \\
(-41.38 \%)\end{array}$ & $\begin{array}{c}8.38 \pm 0.60 \mathrm{~h} \\
(-54.51 \% .)\end{array}$ & $\begin{array}{l}7.43 \pm 0.43 \mathrm{~h} \\
(-62.94 \%)\end{array}$ \\
\hline $\begin{array}{c}\text { Level of } \\
\text { significance }\end{array}$ & NS & $* *$ & $* *$ & $* *$ & ** & $* *$ & $* *$ \\
\hline
\end{tabular}

$\mathrm{NS}=$ Not significant, $* *=\mathrm{P}<0.01$, values in each column bearing dissimilar letter(s) differed significantly, $\%$ change in diabetic control was calculated against normal control and rests were computed against diabetic control group at day 90 .

\section{Blood serum TCh and TGA}

Table 3 demonstrates the level of TCh and TGA in serum of normal and experimental groups of rats. A significant elevation of $\mathrm{TCh}(26.60 \%)$ and TGA $(47.02 \%)$ was observed in diabetic rats group $\left(\mathrm{T}_{2}\right)$, when compared with the normal control $\left(\mathrm{T}_{1}\right)$ at the end of the experiment (day 90).
Treatment with $M$. charantia fruits extracts glibenclamide decreased TCh levels of $\operatorname{group}_{3}(12.88 \%), \quad$ group $_{4}(14.44 \%)$, group $_{5}(17.21 \%)$, and group $\mathrm{T}_{6}(30.17 \%)$, TAG levels of group $_{3}(30.30 \%), \quad$ groupT $_{4}(33.84 \%), \quad$ groupT $_{5}$ $(37.43 \%)$, and group $\mathrm{T}_{6}(53.09 \%)$ respectively at the time of 90 days when compared with the diabetic control rats. 
Table 4. Effects of aqueous extract of $M$. charantia fruits and Glibenclamide on TCh and TGA level (mg/dl) in STZ treated diabetic rats (at what day 15 or 90 )

\begin{tabular}{|l|l|l|}
\hline \multicolumn{1}{|c|}{ Group } & \multicolumn{1}{|c|}{ TCh } & \multicolumn{1}{c|}{ TGA } \\
\hline $\begin{array}{l}\mathrm{T}_{1} \\
\text { Normal Control }\end{array}$ & $74.63 \pm 0.84 \mathrm{e}$ & $65.98 \pm 1.04 \mathrm{bc}$ \\
\hline $\begin{array}{l}\mathrm{T}_{2} \\
\text { Diabetic Control }\end{array}$ & $94.48 \pm 1.36 \mathrm{a}(+26.60 \%)$ & $97.01 \pm 1.14 \mathrm{a}(+47.02 \%)$ \\
\hline $\begin{array}{l}\mathrm{T}_{3} \\
\text { Diabetic + MCFEt-250mg }\end{array}$ & $82.31 \pm 0.56 \mathrm{~b}(-12.88 \%)$ & $67.62 \pm 1.11 \mathrm{~b}(-30.30 \%)$ \\
\hline $\begin{array}{l}\mathrm{T}_{4} \\
\text { Diabetic + MCFEt-500mg }\end{array}$ & $80.83 \pm 1.04 \mathrm{c}(-14.44 \%)$ & $64.18 \pm 0.92 \mathrm{c}(-33.84 \%)$ \\
\hline $\begin{array}{l}\mathrm{T}_{5} \\
\text { Diabetic + MCFEt-750mg }\end{array}$ & $78.22 \pm 0.47 \mathrm{~d}(-17.21 \%)$ & $60.70 \pm 1.02 \mathrm{~d}(-37.43 \%)$ \\
\hline $\begin{array}{l}\mathrm{T}_{6} \\
\text { Diabetic + Glibenclimide-5mg }\end{array}$ & $65.97 \pm 1.78 \mathrm{f} \mathrm{(-30.17 \% )}$ & $45.50 \pm 0.57 \mathrm{~d}(-53.09 \%)$ \\
\hline Level of significance & $* *$ & $* *$ \\
\hline
\end{tabular}

NS=Not significant, $* *=\mathrm{P}<0.01$, values in each column bearing dissimilar letter(s) differed significantly, $\%$ change in diabetic control was calculated against normal control and rests were computed against diabetic control group at day 90 .

Effect of M. charantia on serum Asparate Transaminenase (AST), Alanine Transaminenase (ALT), Alkaline Phosphatase(ALP)

Table 4 shows the activities of AST, ALT and ALP of experimental rats. Compared with normal rats, diabetic rats showed significantly more activities of serum AST, ALT and ALP by $88.56 \%, 673.87 \%$ and $179.91 \%$ respectively. Treatment with aqueous extract of $M$. charantia of all experimental groups significantly reduced the activity of AST ALT and
ALP when compared with the diabetic control rats $(\mathrm{p}<0.01)$. The administration of $M$. charantia (Karala) fruits extract brought down AST values of groupT $\mathrm{T}_{3}$ $(19.75 \%)$, group $\mathrm{T}_{4}(22.56 \%)$, group $\mathrm{T}_{5}(27.95 \%)$, and group $_{6}(43.26 \%)$, ALT values of group $\mathrm{T}_{3}(15.37 \%)$, group $_{4}(16.68 \%)$, group $\mathrm{T}_{5}(22.25 \%)$, and group $\mathrm{T}_{6}$ (36.70\%) and ALP values of group $\mathrm{T}_{3}(19.49 \%)$, group $\mathrm{T}_{4}(22.67 \%)$, group $\mathrm{T}_{5}(25.19 \%)$ and group $\mathrm{T}_{6}$ $(18.37 \%)$ respectively at the time of 90 days when compared with the diabetic control rats.

Table 5. Effects of aqueous extract of $M$. charantia fruits and Glibenclamide on AST, ALT and ALP level (U/l) in STZ treated diabetic rats (at what day 15 or 90)

\begin{tabular}{|l|c|c|c|}
\hline \multicolumn{1}{|c|}{ Group } & AST(U/I) & ALT(U/l) & ALP(U/I) \\
\hline $\mathrm{T}_{1}$ & & & $62.18 \pm 1.00 \mathrm{e}$ \\
Normal Control & $51.38 \pm 1.16 \mathrm{f}$ & $10.15 \pm 0.31 \mathrm{e}$ & $174.05 \pm 1.16 \mathrm{a}$ \\
\hline $\mathrm{T}_{2}$ & $96.88 \pm 1.13 \mathrm{a}$ & $78.55 \pm 0.40 \mathrm{a}$ & $(+87.08)$ \\
Diabetic Control & $(+46.97 \%)$ & $(+87.09 \%)$ & $140.12 \pm 0.81 \mathrm{c}$ \\
\hline $\mathrm{T}_{3}$ & $77.75 \pm 0.72 \mathrm{~b}$ & $66.48 \pm 0.62 \mathrm{~b}$ & $(-15.37)$ \\
Diabetic + MCFEt-250mg & $(-19.75 \%)$ & $(-15.37 \%)$ & $134.60 \pm 0.90 \mathrm{c}$ \\
\hline $\mathrm{T}_{4}$ & $75.02 \pm 0.79 \mathrm{c}$ & $65.45 \pm 0.95$ & $(-16.68)$ \\
Diabetic + MCFEt-500mg & $(-22.56 \%)$ & $(-16.68 \%)$ & $130.20 \pm 0.79 \mathrm{~d}$ \\
\hline $\mathrm{T}_{5}$ & $69.80 \pm 0.79 \mathrm{~d}$ & $61.07 \pm 0.82 \mathrm{c}$ & $(-22.25)$ \\
$\mathrm{Diabetic}$ MCFEt-750mg & $(-27.95 \%)$ & $(-22.25 \%)$ & $142.07 \pm 0.58 \mathrm{~b}$ \\
\hline $\mathrm{T}_{6}$ & $55.02 \pm 0.69 \mathrm{e}$ & $49.72 \pm 0.80 \mathrm{~d}$ & $(-36.70)$ \\
Diabetic + Glibenclimide-5mg & $(-43.26 \%)$ & $(-36.70 \%)$ & $* *$ \\
\hline Level of significance & $* *$ & $* *$ & \\
\hline
\end{tabular}

NS=Not significant, $* *=\mathrm{P}<0.01$, values in each column bearing dissimilar letter(s) differed significantly, $\%$ change in diabetic control was calculated against normal control and rests were computed against diabetic control group at day 90. 


\section{Discussion}

STZ is the drugs that selectively destroy $\beta$-cells, insulin producing pancreatic endocrine cells, and thus induce experimental diabetes mellitus (Hsu and Crump 1989; Brenna et, al; 2003). The possible mechanism by which MC fruits bring about its hypoglycemic action may be potentiating the insulin effect of plasma by increasing either the pancreatic secretion of insulin from the $\beta$-cells of pancreatic islets or directive protection of $\beta$-cells (Krawinkel and Keding, 2006).

The dose-dependent hypoglycemic effect of $M$. charantia fruits detected in the present study considered as the direct evidence that MC fruits has relatively favorable anti-diabetic effects. More favorable effects were detected in group(T5) MCFEt$750 \mathrm{mg} / \mathrm{kg}$ bd wt decrease of the blood glucose levels compared to that of other treated groups in this study. Our findings are similar to those reported previously including Ojewole et al. (2006); Miura et al.(2004); and Shibib et al. (1993). STZ induced diabetes is characterized by severe loss in body weight (AlShamaony et,al; 1994) However, it did not normalize the body weight completely as it remained lesser than normal control rats. (Chen and Ianuzzo 1982). In the present work STZ diabetic rats exhibited marked hypercholesterolemia and hypertri-glyceridmia. Our results are in accordance with the findings of Mathe (1995), Ulicna, et al. 1996) and Wasan et al. (1998) who recorded marked increases of serum cholesterol and triglycerides levels and abnormalities in lipoprotein levels in alloxan and streptozotocin diabetic animals. These abnormalities certainly play a role in the increased risk for cardiovascular disease (Tsutsumi et al., 1995). Treatments of STZ diabetic rats in the present study observed that with $\mathrm{MC}$ doses produced marked decreases of serum triglycerides; total cholesterol level which was depended with dose concentrations. These observations indicate that the hypocholesterolemic action of the MC extracts is attributed to the ability to suppress cholesterol biosynthesis. Furthermore, correlation between insulin levels, triglycerides and cholesterol fractions underline the important role of the hormone in the control of blood lipid levels. Indeed hepatic VLDL triglyceride synthesis and secretion are regulated by insulin (Marles and Faresworth, 1995).

In agreement with our results, (Seham et al., 2006; Sathishseker and Subramamian. 2005 ) reported that Momordica chrantia fruits extract have pronounced antihyperlipidemeic properties. Effect of aqueous extracts of $M$. charantia on serum Asparate Transaminase (AST), Alanine Transaminase (ALT) and Alkaline Phosphatase (ALP) activities are presented in Table (4). The STZ induced diabetic rats $\left(\mathrm{T}_{2}\right)$ showed highly significant increase in AST activity (46.97\%, $\mathrm{P}<0.01)$, when compared with normal control group $\left(\mathrm{T}_{1}\right)$. Meanwhile, The administration of aqueous extracts of $M$. charantia group $\mathrm{T}_{3}, \mathrm{~T}_{4}$ and $\mathrm{T}_{5}$ caused a significance decrease by $(-19.75,-22.56$ and $-27.95 \%$ respectively, $\mathrm{P}<$ $0.01)$. STZ induced diabetic rats a highly significant increase in ALT activity by $(87.09 \%, \mathrm{P}<0.01)$ as compared with normal control ones. The administration of aqueous extracts of $M$. charantia STZ diabetic rats significantly improved the ALT activity by $(-15.37,-16.68$ and $-22.25 \%$, respectively, $\mathrm{P}<0.01$ ) as compared to normal diabetic group (Table 4). Compared with in treated groups the rate of reduction was found in group $\left(\mathrm{T}_{5}\right)$-MCFEt-750mg/kg bd.wt., From Table 4 it was also found that significantly increased the alkaline phosphatase activity in STZ diabetic rats $(+87.08, \mathrm{P}<0.01)$. On the other hand, STZ diabetic rats treated with different doses of MC extracts $250,500,750 \mathrm{mg} / \mathrm{kg}$ bd.wt., exhibited significant change in alkaline phosphatase compared to untreated diabetic rats $(-15.37,-16.68$ and $-22.25 \% \mathrm{P}<0.01)$. Accelerated gluconeogenesis, negative nitrogen balance and muscle wasting are among the hallmarks of uncontrolled diabetes (Buse et al. 1972). There is a catabolism of branched amino acids and alanine release by skeletal muscle (Odessey et al.1972). Glutamate is an obligate precursor of alanine and glutamine production by muscles. The later two amino acids comprise more than $50 \%$ of all the amino acids released by the muscle, alanine being the preferred amino acid precursor of gluconeogenesis in the liver and glutamine in the kidney (Cahill et al. 1972). A close association between ALT activity and diabetse has been reported by Ohleson et al. (1988). The activity of AST and ALP were enormously elevated $(\mathrm{P}<0.01)$ by $46 \%$ and $87.09 \%$ respectively in uncontrolled diabetes from that of normal, indicative of enhanced gluconeogenesis in uncontrolled diabetes.

A number of researchers have reported that the extract of the unripe fuits and seeds of $\mathrm{MC}$ reduced AST and ALT.( Abd El Sattran El Batran et al. 2006; Sathishsekar and Subramamian 2005, and Senanyake et al. 2004). Our data were a good agreement with other investigators (Sathishsekar and Subramamian 2005) who stated that the positive effects of MC extracts on insulin activity suggested possible role of this MC extract in improving AST and ALT levels in diabetic rats. It was reported by Mujeeb et al (2009) antidiabetic activity of $A$. squamosa root extract in STZ induced hyperglycemia in rats. STZ induced diabetes mellitus and insulin deficiency lead to 
increased blood glucose level. When A. squamosa root extract was administered to diabetic rats, hypoglycaemia was observed after $2 \mathrm{hrs}$, with the maximum effect being seen at $6 \mathrm{~h}$. From the results it is assumed that the root extract could be responsible for stimulation of insulin release and observed restoration of blood glucose level. Further, the observed decreased blood glucose lowering effect of the extract in STZ induced diabetic rats could also possibly be due to increased peripheral glucose utilization. It has been reported that using medicinal plant extract to treat STZ-induced diabetic rats results in activation of $\beta$-cells and insulinogenic effects. The antihyperglycemic activity of the Aq. extract of Annona squamosa roots was comparable with glibenclamide, a standard hypoglycaemic drug. The results of this study has a great resemblance with our present study in term of efficacy. The activity of alkaline phosphatase in the various groups represented in Table 4 showed an incredible increase in diabetic control by $87.08 \% \quad(p<0.01)$ when compared to normal control. Increased activities of phosphatases in diabetes may affect the transport of metabolites across the membrane due to alteration in dephosphorylation reactions. Enhanced levels of phosphatases cause increased intracellular inorganic phosphate, which further affects the efficiency of ionic pumps which is reflected in decreased activities of Na+ K+ ATPases in diabetes (Sailaja, 2000).

M. charantia fruits extract treatment brought down such elevated levels of ALP significantly $(\mathrm{p}<0.01)$ by 15.37, 16.68 and $22.25 \%$ in case of doses 250, 500, and $750 \mathrm{mg} / \mathrm{kg}$ bd.wt.,. Tennekoon, et al. (1994) has been reported that oral administration of $M$. charantia fruit juice and seed extract daily @1ml/100g body weight for 30 days significantly reduced alkaline phosphatase concentrations in the liver of rats. So that the results of the present study have supported the finding of (Tennekoon et al. 1994) in diabetic rats treated with $M$. charantia fruits juice and seed extract. In conclusion, on the basis of our results the treatment of $M$. Charantia fruits has hyperglycemia and antihyperlipidemic effect against STZ induced diabetic rats. It was dose dependent, but it was not highly effective in comparison of glibenclamide. The actual ingredient(s) present in this extract for such correction is not delineated from this present study. Further investigations are in progress to elucidate the detailed mechanism of hypoglycemic and hypolipidemic effects in STZ induced diabetic rats.

\section{References}

Al-Shamaony, L., Al-Khazraji, S. M. and Twaiji, H. A. 1994. Hypoglycemic effect of animals. $J$ Ethnopharmacol, 43: 167.

Bailey, C. J. and Day, C. 1989. Traditional plant medicines as treatments for diabetes. Diabetes Care, 12:553-564.

Batran, A. E. S. E. S., El-Gengaihi S.E. and Shabrawy, O.A. 2006. Some toxicological studies of L. on albino rats in normal and alloxan diabetic rats. J. Ethnopharmacol., 108:236-242

Brenna, O., Qvigstad, G., Brenna, E. and Waldum, H. L. 2003. Cytotoxicity of Streptozotocin on. Neuroendocrine Cells of the Pancreas and the Gut. Dig. Dis. Sci., 48: 906-910.

Bhattaram, V. A., Ceraefe, M., Kohlest, C., Ves M. and Deundorf, H. 2002. Pharmacokinetics and bioavailability of herbal medicinal products. Phytomed., 9: 1-36.

Buse, M. G., Biggers, J. F. and Friderici, K. H. 1972. Oxidation of branched chain amino acids by isolated hearts and diaphragms of the rat. The effect of fatty acids, glucose and pyruvate respiration. J. Biol. Chem 247: 8085-96.

Cahill, G. F., Aoki, T. T. and Marless, E. B. 1972. Insulin and muscle protein, In Hand book of Physiology, Sec. Endocrinology, Vol I. Steiner,DF., Frienkel, N.,Eds; Washington. D.C. American Physiololgical Society, 563p.

Chattopadhyay, S., Ramanathan, M., Das, J. and Bhattacharya, S. K. 1997. Animal models in experimental diabetes mellitus. Indian J Exp Biol, 35: 1141. Chen, V. and Ianuzzo, C. D. 1982. Dosage effect of streptozotocin on rat tissue enzyme activities and glycogen concentration. Can J Physiol Pharmacol. 60: 1251.

Chevallier, A. 1996. The Encyclopedia of Medicinal Plants. $1^{\text {st }}$ edn., DK Publishing Inc., New York, USA.

Duncan, D. B. 1955. Multiple ranges and multiple F test. Biometrics, 11: 1-42.

Freed, R. D. 1992. MSTAT Director. Crop and Soil Sciences Department, Michigan State University, USA.

Ganguly, C., De, S. and Das, S. 2000. Prevention of carcinogen-induced mouse skin papilloma by whole fruit aqueous extract of Mormordica charantia. Eur J Cancer Prer., 9: 283.

Granner, D. K. 1996. Hormones of the Pancreas and Gastrointestinal Tract. In: Murray, R.K., Granner, R.K., Mayes, P.A. and Rodwell, V.W. (Eds). Harper's Biochemistry, 24th Edn., Appleton and Lange, Connecticut, USA, pp. 586-587.

Hsu ,W. H. and Crump, M. H. 1989. "Veterinary Endocrinology and Reproduction,"ed. by 
McDonald L. E., Pineda M. H., Lea \& Febiger, Philadelphia, 1989, pp. 186-201.

Huang, T. H., Kota, B. P., Razmovski, V. and Roufogalis, B. D. 2005. Herbal or natural medicines as modulators of peroxisome proliferator-activated receptors and related nuclear receptors for therapy of metabolic syndrome. Basic Clin. Pharmacol. Toxicol., 96: 3-14.

Jayasooriya, A. P., Sakono, M., Yuxizaki, C., Kawano, M., Yanmoto, K. and Fukuda, N. 2000. Effects of Mormordica charantia powder on serum glucose levels and various lipid parameters in rats fed with cholesterol-free and cholesterolenriched diets. J Ethnopharmacol 72: 331.

Kern, T. S. and Engerman, R. L. 1987. Kidney morphology in experimental hyperglycemia. Diabetes, 36:244-249.

King, H., Aubert, R. E. and Herman, W. H. 1998. Global burden of diabetes 1995-2025: prevalence, numerical estimates, and projections. Diabetes Care, 21: 1414-1431.

Krawinkel, M. B. and Keding, G. B. 2006. Bitter gourd (M. charantia): A dietary approach to hyperglycemia. Nutr. Rev., 64: 331-337.

Loew, D. and Kaszkin, M. 2002. Approaching the problem of bioequivalence of herbal medicinal products. Phytother. Res., 16: 705-711.

Lyra, R. ; Oliveira, M. ; Lins, D. and Cavalcanti, N. 2006. Prevention of type 2 diabetes mellitus. Arq. Bras. Endocrinol. Metabo,. 50: 239-249.

Mahomed, I. M. and J.A. Ojewole, 2003. Hypoglycemic effect of Hypoxis hemerocallidea corm (African potato) aqueous extract in rats. Method Find. Exp. Clin. Pharmacol., 25: 617623.

Markuszewski, L. ; Bodalska, J. ; Kaminski, G. and Kuberska-Kedzierska, M. ; 2006. Usefulness of measurement of glucose and glycosylated hemoglobin levels in patients with acute coronary syndrome as number predictors of stenotic coronary arteries shown in coronary arteriography. Pol. Merkuriusz Lek., 20: 270-273.

Marles, R.J. and Farns Worth, N. R. (1995) : antidiabetic plants and their active constituents. Phytomedicine, 2 (2) : 137-189.

Mathe, D. 1995 . dyslipidemia and diabetes animal models. Diabet. Metab. 21 (2): 106-111.

Miura, T., Itoh, Y., Iwamoto, N., Kato, M. and Ishida, T. 2004. Suppressive activity of the fruit of $M$. charantia with exercise on blood glucose in type 2 diabetic mice. Biol. and Pharmaceutical Bull., 27: 248-250.

Morel, D. W. and Chisolm, G.M. 1989. Antioxidant treatment of diabetic rats inhibits lipoprotein oxidation and cytotoxicity. J. Lipid Res., 30:1827-1834.

Mujeeb, M., Khan, S. A., Ali, M., Mall, A. and Ahmad, A. (2009) : Antidiabetic Activity Of The Aqueous Extract Of Annona Squamosa In Streptozotocin Induced- Hyperglycemic Rats. The Pharma Research, 2: 59-63.

Neef, H., Declercq, P. and Laekeman, G. 1995. Hypoglycaemic activity of selected European plants. Phytother Res., 9: 45-48.

Odessey, R., Khairallah, E. and Goldberg, A. L. 1972. Origin and possible significance of alanine production by skeletal muscle. J Biol Chem. 249: 7623-9.

Ohlson, L.O., Larsson, B., Bjomtorp, P., Eriksson, H., Svardsudd, K., Welin, L., Tibblin, G. and Wilhelmsen, L. 1988. Risk factors for Type 2 (noninsulin-dependent) diabetes mellitus. Thirteen and one-half years of follow-up of the participants in a study of Swedish men born in 1913. Diabetotogia 31: 798-737.

Ojewole, J. A., Adewole, S. O. and Olayiwola, G. 2006. Hypoglycemic and hyportensive effects of $M$. charantia Linn (Cucurbitaceae) whole-plant aqueous extract in rats. Cardiovasc. J. South Africa., 17: 227-232.

Oliver-Bever, B. 1986. Oral hypoglycemic action of medicinal plants in tropical West Africa. Cambridge University Press, London, pp. 245-267.

Rai, M. K., 1995. A review on some antidiabetic plants of India. Ancient Science of Life, 14: 42-54.

Sailaja, Y. R. 2000. Biochemical studies during maturation of breticulocytes to erythrocytes in type 2 Diabetes. Ph.D., thesis, Sri Krishnadevaraya University, Anantapur.

Sakamoto, K., Yonoki, Y., Fujioka, T., Matsumura, M., Mitsuta, Y.; Sano, M. and Saito, M. 2006. Disappearance of glibenclamide-induced hypoglycemia in Wistar-Kyoto rats. Biol. Pharm. Bull., 29: 574-576.

Sathishsekar, D. and Subramanian, S. 2005. Beneficial effects of $M$. charantia seeds in the treatment of STZ-induced diabetes in experimental rats. Biol. Pharm. Bull., 28: 978-983.

Scheen, J. A. 1997. Drug treatment of non-insulin dependent diabetes mellitus in the 1990s. Achievement and future development. Drug, 54:355-368.

Batran S. A. E. S. E. S. E. El-Gengaihi and Shabrawy, O. A. E. 2006. Some toxicological studies of $M$. charantia $\mathrm{L}$. on albino rats in normal and alloxan diabetic rats. J. of Ethnopharmacol. 24: 236-242.

Senanyake, G.V., Maruyama, M., Shibuya, K., Sakono, M., Fukuda, N., Morishita, T., Yukizaki, C., Kawano, M. and Ohta, H. 2004 the effects of bitter melon ( $M$. charantia) extracts on serum and liver lipid parameters in hamsters fed cholesterol-free 
and cholestrol-enricher diets. J.Nutr.Sci. Vitaminol., 50: 253-257.

Shibib, B. A., Khan, L. A. and Rahman, R. 1993. Hypoglycemic activity of Coccinia indica and $M$. charantia in diabetic rats: depression of the hepatic glyconeogenic enzymes glucose 6-phosphatase and fructose 1,6 bisphosphatase and elevation of both liver and red cell count enzyme glucose-6phosphate dehydrogenase. Biochem.J., 292, $267-$ 270.

Shukla, R., Sharma, S.B., Puri, D., Prabhu, K. M. and Murthy, P. S.2000. Medicinal plants useful in diabetes. Journal of Clinical Biochemistry 15: (Suppl) 169-177.

Shukla, R., Sharma, S. B., Puri, D., Pabhu, K. M. and Murthy, P. S. 2000. Medicinal plants for treatment of diabetes mellitus. Indian J. Clinical. Biochem. (Suppl.), 15: 169-177. Am. J. Biochem. \& Biotech., 2 (4): 154-160.
Tennekoon, K.H., Jeevathayaparan, S., Angunawala, P., Karunanayake, E. H. and Jayasinghe, K.S. 1994. Effect of $M$. charantia on key hepatic enzymes. $J$. Ethnopharmacol., 44: 93-97.

Tsutsumi, K., Inoue, Y., Shima, A. and Murase, T.1995. Correction of hypertriglyc - eridemia with low highdensity lipoprotein cholesterol by the novel compound No. 1886, a lipoprotein lipasepromoting agent, in STZ induced diabetic rats. Diabetes, 44 : 414- 417.

Ulicna, O., Volkovova, K. and Istvanova, B. 1996. Bioenergetics of liver mitochondria in rats in experimental insulindependent diabetes Bratisl. Lek.listy, 97 (10): 619-624.

Wasan, K. M., N.G, S. P., Wong, W. and Rodrigues, B.B. 1998. Streptozotocin and alloxan- induced diabetes modifies total plasma and lipoprotein lipid concentration and composition without altering cholesterol ester transfer activity. Pharmacol. Toxicol.,83 : 169 - 175. 